DOI: 10.18276/sip.2016.43/3-41

\title{
Robert Wolny*
}

Uniwersytet Ekonomiczny w Katowicach, Wydział Ekonomii, Katowice, Polska

\section{ZACHOWANIA NABYWCZE W INTERNECIE E-KONSUMENTÓW W AUSTRII, NIEMCZECH I SZWAJCARII}

\begin{abstract}
Streszczenie
Celem artykułu jest przedstawienie wybranych uwarunkowań zachowań nabywczych e-konsumentów w Austrii, Niemczech i Szwajcarii oraz przedstawienie wyników badań dotyczących zachowań nabywczych w internecie w tych krajach. W artykule wykorzystano wyniki badań bezpośrednich przeprowadzonych techniką ankiety on-line (WEB) w latach 2014-2015. Z przeprowadzonych badań wynika, że e-konsumenci z wybranych krajów europejskich są aktywnymi i świadomymi nabywcami produktów w internecie. Chętnie korzystają z internetowych źródeł informacji, a podstawowe czynniki determinujące zakupy w internecie to możliwość porównywania oferty różnych producentów oraz możliwość zakupu 24 godziny na dobę.
\end{abstract}

Słowa kluczowe: zachowania nabywcze, e-konsument, Austria, Niemcy, Szwajcaria

\section{Wstęp}

Zachowania nabywcze $\mathrm{w}$ internecie obserwuje się $\mathrm{w}$ krajach europejskich od ponad 20 lat. W tym czasie zaszły (i zachodzą w dalszym ciągu) duże zmiany w zachowaniach e-konsumentów, które związane są z przedmiotem zakupu, czynnikami determinującymi zakupy, źródłami informacji o ofercie handlowej. Zachowania e-konsumentów to zorganizowany i ukierunkowany ciąg reakcji e-konsumentów,

\footnotetext{
* Adres e-mail: robert.wolny@ue.katowice.pl.
} 
zachodzących w świecie realnym lub/i w internecie, a wywołanych impulsami wynikającymi z dążenia do zaspokojenia potrzeb (Jaciow, Wolny, 2013, s. 11). Zachowania e-konsumentów to wszystkie te czynności (reakcje), które mogą zachodzić zarówno w internecie, jak i świecie realnym, ale co bardzo ważne - muszą być wykonywane przez e-konsumentów (czyli osoby zaspokajające swoje potrzeby konsumpcyjne dobrami i usługami kupionymi w internecie) (Jaciow, Wolny, 2013, s. 11). Czy zatem podejmowane przez e-konsumentów czynności zmierzające do zakupu częściej mają miejsce w internecie, czy w świecie realnym? Czy e-konsumenci w przyszłości częściej będą dokonywać zakupu wybranych produktów on-line?

Celem artykułu jest przedstawienie wybranych uwarunkowań zachowań nabywczych e-konsumentów w Austrii, Niemczech i Szwajcarii oraz przedstawienie wyników badań dotyczących zachowań nabywczych $\mathrm{w}$ internecie $\mathrm{w}$ tych krajach ${ }^{1}$. Badania w Austrii przeprowadzono na próbie 550 osób (63,3\% badanej próby stanowiły kobiety, zaś 36,7\% - mężczyźni; średni wiek badanych wynosił 26,4 lat; najmłodszy badany miał 16 lat, a najstarszy 75 lat; 73,3\% badanych było aktywnych zawodowo). Badania w Niemczech przeprowadzono na próbie 900 osób (59,8\% badanej próby stanowiły kobiety, a 40,2\% mężczyźni; średni wiek badanych wynosił 30,2 lat; najmłodszy badany miał 17 lat, a najstarszy 70 lat; 83,4\% badanych było aktywnych zawodowo). Badania w Szwajcarii przeprowadzono na próbie 450 osób (58,6\% badanej próby stanowiły kobiety, a 41,4\% mężczyźni; średni wiek badanych wynosił 27,7 lat; najmłodszy badany miał 16 lat, a najstarszy 60 lat; 82,4\% badanych było aktywnych zawodowo).

\section{Uwarunkowania zachowań nabywczych e-konsumentów z wybranych krajów europejskich}

Zachowania nabywcze e-konsumentów, jakkolwiek determinowane i zależne głównie od czynników wewnętrznych, nie pozostają bez wpływu uwarunkowań zewnętrznych. Podstawy dla funkcjonowania e-konsumentów w najszerszym wymiarze tworzy zespół warunków i czynników składających się na tak zwane makro-

\footnotetext{
Badania bezpośrednie przeprowadzono techniką ankiety on-line (WEB) przy wykorzystaniu platformy survaymonkey.com w okresie październik 2014 r. - maj 2015 r. w 14 krajach europejskich (Austria, Czechy, Francja, Hiszpania, Irlandia, Niemcy, Polska, Portugalia, Rumunia, Słowacja, Szwajcaria, Szwecja, Wielka Brytania, Włochy) wśród aktywnych e-konsumentów. W artykule przedstawione zostaną wyniki badań z wybranych krajów: Austrii, Niemiec i Szwajcarii. Badania są kontynuacją rozpoczętych w 2012 r. badań w wybranych krajach Europy. Szerzej na ten temat: Jaciow, Wolny i Stolecka-Makowska (2013).
} 
otoczenie, do którego należą uwarunkowania demograficzne, społeczne, kulturowe, ekonomiczne, prawne i technologiczne (Jaciow, Wolny, Stolecka-Makowska, 2013, s. 41). Makrootoczenie e-konsumentów powiązane jest z tak zwanym mikrootoczeniem, w którym istotny jest stan infrastruktury handlowej (w tym przypadku na infrastrukturę składają się sklepy internetowe, portale prowadzące aukcje internetowe oraz producenci prowadzący sprzedaż poprzez własne strony internetowe) oraz oferta podażowa. Mikrootoczenie e-konsumentów tworzy także tak zwana domowa infrastruktura konsumpcyjna (w tym przypadku mieszkanie i jego wyposażenie w urządzenia umożliwiające korzystanie z internetu, np. komputer, tablet itp.).

Dostęp do internetu jest czynnikiem bezpośrednio determinującym aktywność e-konsumentów w sieci. W latach 2006-2014 w badanych krajach rosła liczba gospodarstw domowych mających dostęp do internetu, w tym największy wzrost odnotowano w Austrii (o 29 p.p.). W 2014 roku największy odsetek gospodarstw domowych posiadających dostęp do internetu wśród analizowanych krajów odnotowano w Szwajcarii (o 10 p.p. większy niż w Austrii i o 2 p.p. większy niż w Niemczech) (tabela 1).

Tabela 1. Gospodarstwa domowe posiadające dostęp do internatu w wybranych krajach europejskich w latach 2006-2014 [\%]

\begin{tabular}{|l|c|c|c|c|c|c|c|c|c|}
\hline \multicolumn{1}{|c|}{ Wyszczególnienie } & 2006 & 2007 & 2008 & 2009 & 2010 & 2011 & 2012 & 2013 & 2014 \\
\hline Austria & 52 & 60 & 69 & 70 & 73 & 75 & 79 & 81 & 81 \\
\hline Niemcy & 67 & 71 & 75 & 79 & 82 & 83 & 85 & 88 & 89 \\
\hline Szwajcaria & 71 & 74 & 77 & 80 & 85 & 87 & 90 & 92 & 91 \\
\hline
\end{tabular}

Źródło: http://appsso.eurostat.ec.europa.eu oraz http://www.bfs.admin.ch.

Wielkość zakupów dokonanych w internecie w krajach niemieckojęzycznych przybiera różne rozmiary, jednak jest wyższy niż wśród innych krajów europejskich. Wskaźnikiem, którym można posłużyć się w porównaniach międzynarodowych, jest wskaźnik gospodarki cyfrowej i społeczeństwa informacyjnego DESI (Digital Economy and Society Index²). W 2014 roku w Austrii wskaźnik ten wynosił

\footnotetext{
2 Wskaźnik gospodarki cyfrowej i społeczeństwa cyfrowego opracowany przez Komisję Europejską jest indeksem, który służy ocenie rozwoju krajów Unii w zakresie gospodarki cyfrowej i społeczeństwa cyfrowego. Zagregowano w nim zestaw 5 współczynników dotyczących: łączności (dostępu do internetu), kapitału ludzkiego (umiejętności informatycznych), korzystania z internetu, integracji technologii cyfrowych i cyfrowych usług publicznych. Wskaźnik przyjmuje wartości w przedziale $(0,1)$, a im wyższa jego wartość, tym lepszy jest poziom cyfryzacji danego kraju. Szerzej na ten temat: http://ec.europa.eu/.
} 
0,46 (13 miejsce na liście państw Unii Europejskiej), a w Niemczech 0,49 (miejsce 10) (Szwajcaria jako państwo poza Unią Europejską nie jest tutaj klasyfikowana) ${ }^{3}$. Z kolei według innego wskaźnika - ICT Development Index (IDI $\left.{ }^{4}\right)$ w 2013 roku Szwajcaria znalazła się na 13 miejscu na świecie (IDI $=8,81$ ), Niemcy na 17 miejscu (ICT $=7,70$ ), a Austria na 24 (ICT $=7,62$ ) (Measuring the Information Society Report 2014, s. 37, 42).

W latach 2006-2014 wrosła liczba osób zamawiających przez internet dobra i usługi do własnego użytku prywatnego w badanych krajach europejskich. W Austrii i Niemczech wzrost był niemal dwukrotny. W 2014 roku największy odsetek kupujących w internecie odnotowano w Szwajcarii i Niemczech (ponad 60\%) i był on o 1/3 większy niż w Austrii (tabela 2).

Tabela 2. Kupujący w wybranych krajach europejskich dobra i usługi do użytku prywatnego przez internet w latach 2006-2014 [\%]

\begin{tabular}{|l|c|c|c|c|c|c|c|c|c|}
\hline \multicolumn{1}{|c|}{ Wyszczególnienie } & 2006 & 2007 & 2008 & 2009 & 2010 & 2011 & 2012 & 2013 & 2014 \\
\hline Austria & 23 & 26 & 28 & 32 & 32 & 35 & 39 & 46 & 43 \\
\hline Niemcy & 38 & 41 & 42 & 45 & 48 & 54 & 55 & 60 & 61 \\
\hline Szwajcaria &. &. &. &. & 48 & 55 & 58 & 61 & 62 \\
\hline
\end{tabular}

Źródło: http://appsso.eurostat.ec.europa.eu oraz http://www.bfs.admin.ch.

Charakteryzując infrastrukturę handlu elektronicznego, należy zwrócić uwagę na największe sklepy/aukcje internetowe funkcjonujące w krajach niemieckojęzycznych. Co charakterystyczne, wiele sklepów internetowych jest popularnych w co najmniej dwóch z badanych krajów (należą do nich: Amazon, Zalando, Conrad, H\&M). Największą wartość sprzedaży w 2014 roku w Austrii i Niemczech zanotowano w Amazon (sprzedaż odpowiednio 384,1 mln euro oraz $5787 \mathrm{mln}$ euro), a w Szwajcarii w Digitec (sprzedaż 414,4 mln euro). W Austrii drugie miejsce zajmuje Uniwersal (sprzedaż 107,5 mln euro), w Niemczech OTTO (sprzedaż 1880 mln euro), a w Szwajcarii Amazon (sprzedaż 260,3 mln euro) (tabela 3).

\footnotetext{
3 https:/ec.europa.eu/digital-agenda/en/scoreboard/germany\#1-connectivity.

$4 \quad$ Wskaźnik rozwoju ICT (IDI) to kompozycja 11 elementów stworzona w celu monitorowania i porównywania osiągnięć w zakresie technologii telekomunikacyjnych (ICT) w różnych krajach.
} 
Tabela 3. Sprzedaż w 10 największych sklepach internetowych w Austrii, Niemczech i Szwajcarii w 2014 roku [mln euro]

\begin{tabular}{|l|c|c|c|}
\hline Wyszczególnienie & Austria & Niemcy & Szwajcaria \\
\hline Amazon & 384,1 & 5787,0 & 260,3 \\
\hline OTTO & 64,1 & 1880,0 & - \\
\hline Zalando & 72,5 & 702,0 & 203,1 \\
\hline Notebooksbilliger & - & 498,9 & - \\
\hline Conrad & 35,3 & 389,6 & - \\
\hline Digitec & - & - & 414,4 \\
\hline BonPrix & - & 410,5 & - \\
\hline Cyberport & - & 404,0 & - \\
\hline Tchibo & - & 400,0 & - \\
\hline Alternate & - & 366,9 & - \\
\hline H\&M & 32,6 & 303,7 & - \\
\hline Nespresso & - & - & 260,0 \\
\hline LeShop & - & - & 128,5 \\
\hline Brack.ch & - & - & 113,8 \\
\hline Uniwersal & 107,5 & - & - \\
\hline Coop@home & - & - & 83,7 \\
\hline Microspot & - & - & 82,1 \\
\hline NetooSHOP & - & - & 61,9 \\
\hline DeinDetal & - & - & 52,8 \\
\hline Edusho & 40,0 & - & - \\
\hline DiTech & 37,7 & - & - \\
\hline
\end{tabular}

Źródło: opracowanie własne na podstawie: http://ecommercenews.eu.

Konsument świadomy możliwości różnych form zakupu produktów, posiadający techniczne możliwości zakupu on-line i oceniający alternatywy miejsc zakupu na korzyść sklepów/aukcji internetowych rozpoczyna proces kupowania w internecie. Zakupu on-line są popularne wśród europejskich konsumentów, jednak zakres zakupu, determinanty zakupu, jak i źródła informacji o ofercie są różne w poszczególnych krajach.

\section{Postępowanie e-konsumentów z Austrii}

Respondenci z Austrii chętnie dokonują zakupów on-line, ale dotyczy to częściej produktów trwałych. Ponad połowa badanych kupuje przez internet książki i multimedia, 44,2\% komputery i oprogramowanie, a 39\% artykuły sportowe i turystyczne. Kosmetyki przez internet kupuje 18,3\%, a żywność jedynie 4,2\% badanych Austriaków (rysunek 1). 
Rysunek 1. Produkty kupowane w internecie przez e-konsumentów z Austrii [\%]

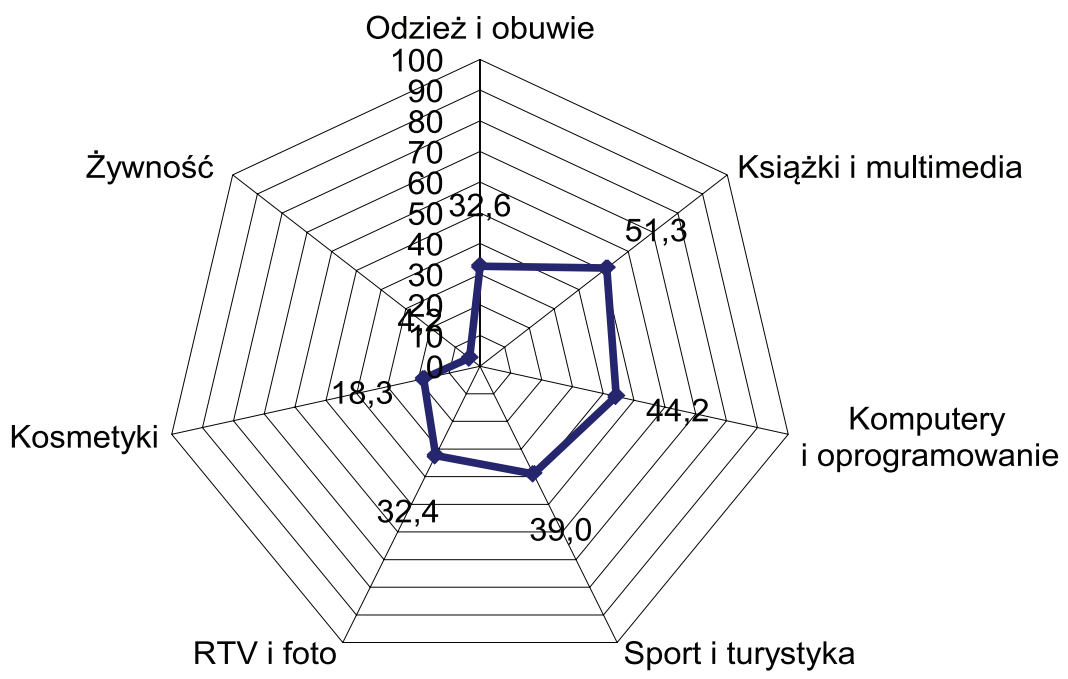

Źródło: opracowanie własne.

Prawie 3/4 badanych Austriaków jako przyczynę dokonywania zakupów on-line wskazuje możliwość porównywania oferty produktów różnych producentów. Niemal 2/3: możliwość zakupu 24 godziny na dobę, szeroką ofertę towarową w internecie, niższe ceny oferowanych produktów w porównaniu z placówkami tradycyjnymi oraz wygodę dokonywania zakupów. Na modę dokonywania zakupów on-line wskazało tylko $16,5 \%$ badanych (rysunek 2 ).

Podstawowym internetowym źródłem informacji respondentów z Austrii o ofercie handlowej są strony internetowe producentów. Korzysta z nich ponad połowa badanych szukających informacji o komputerach i oprogramowaniu i niemal co czwarty badany Austriak kupujący żywność. Informacji na forach internetowych szuka ponad połowa respondentów chcących zdobyć informacje o komputerach i oprogramowaniu, a niemal co trzeci badany kupujący odzież i obuwie oraz książki i multimedia korzysta $z$ informacji ze sklepów/aukcji internetowych. Informacje pochodzące z porównywarek cen Austriacy chętnie wykorzystują przy zakupach komputerów i oprogramowania. Mniejsze znaczenie w poszukiwaniu informacji dla respondentów z Austrii ma reklama w internecie, chociaż wykorzystuje ją jako źródło informacji prawie co czwarty kupujący odzież i obuwie (tabela 4). 
Rysunek 2. Przyczyny zakupu produktów przez internet, a nie tradycyjnie, przez e-konsumentów z Austrii [\%]

Możliwość porównywania oferty produktów różnych producentów

Możliwość zakupu 24 godzin na dobę

Szeroka oferta towarowa - duży wybór

Niższa cena oferowanych produktów

Wygoda dokonywania zakupu

Oszczędność czasu

Szczegółowe informacje o produktach

Zakupy są przemyślane

Zakupy w internecie są w modzie

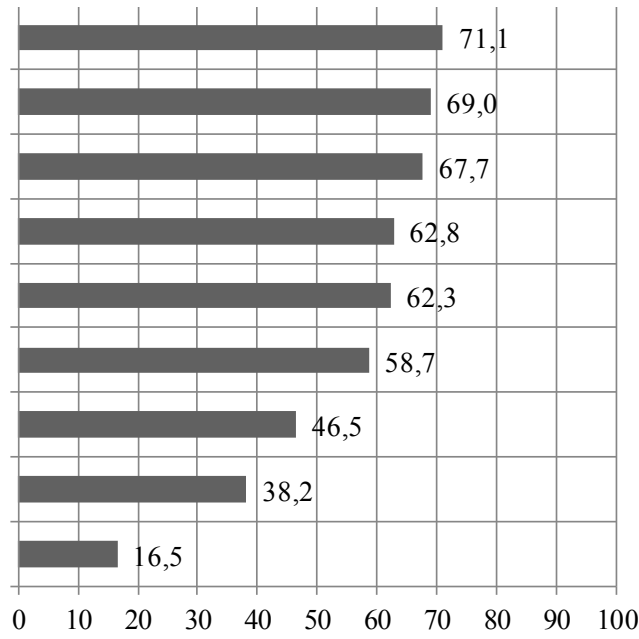

Źródło: opracowanie własne.

Tabela 4. Internetowe źródła informacji o produktach wykorzystywane przez e-konsumentów z Austrii [\%]

\begin{tabular}{|l|c|c|c|c|c|}
\hline \multicolumn{1}{|c|}{ Wyszczególnienie } & $\begin{array}{c}\text { Strony WWW } \\
\text { producentów }\end{array}$ & $\begin{array}{c}\text { Fora } \\
\text { internetowe }\end{array}$ & $\begin{array}{c}\text { Sklepy/aukcje } \\
\text { internetowe }\end{array}$ & $\begin{array}{c}\text { Porównywarki } \\
\text { cen }\end{array}$ & $\begin{array}{c}\text { Reklama } \\
\text { w sieci }\end{array}$ \\
\hline Komputery i oprogramowanie & 55,2 & 50,5 & 28,2 & 44,0 & 14,8 \\
\hline Książki i multimedia & 43,0 & 30,3 & 36,8 & 14,8 & 15,5 \\
\hline Odzież i obuwie & 41,5 & 17,3 & 33,6 & 18,8 & 23,5 \\
\hline RTV i foto & 39,4 & 28,5 & 25,3 & 22,4 & 14,1 \\
\hline Sport i turystyka & 37,5 & 22,0 & 22,4 & 18,4 & 16,6 \\
\hline Kosmetyki & 33,6 & 21,7 & 24,5 & 11,6 & 17,3 \\
\hline Żywność & 24,2 & 13,0 & 11,9 & 10,8 & 13,7 \\
\hline
\end{tabular}

Źródło: opracowanie własne.

\section{Postępowanie e-konsumentów z Niemiec}

Ponad połowa badanych z Niemiec kupuje przez internet książki i multimedia oraz komputery i oprogramowanie, a około $40 \%$ artykuły RTV i fotograficzne, odzież i obuwie oraz artykuły sportowe i turystyczne. Kosmetyki przez internet kupuje 25,4\%, a żywność 8,1\% badanych Niemców (rysunek 3). 
Rysunek 3. Produkty kupowane w internecie przez e-konsumentów z Niemiec [\%]

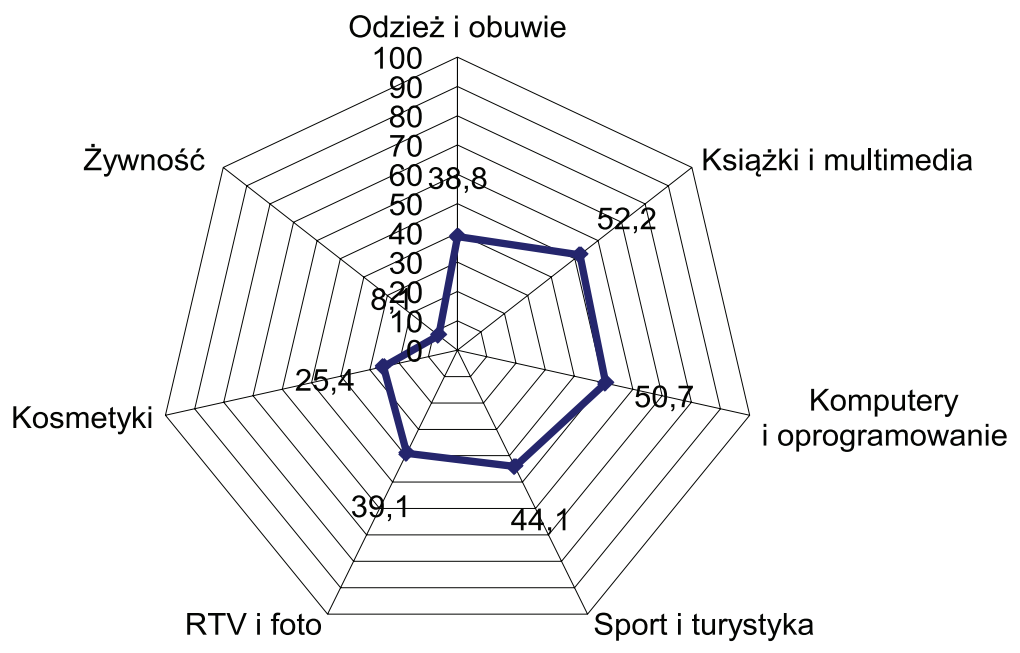

Źródło: opracowanie własne.

Dla badanych z Niemiec najistotniejszym czynnikiem skłaniającym do zakupów on-line jest możliwość dokonywania zakupów 24 godziny na dobę (niemal 3/4 wskazań). Prawie 2/3 badanych wskazuje na możliwość porównywania oferty produktów różnych producentów oraz niższe ceny oferowanych produktów w porównaniu z placówkami tradycyjnymi. Tylko co dziesiąty badany Niemiec deklaruje

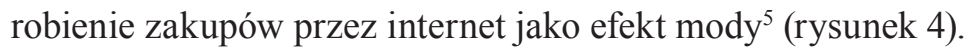

Głównym internetowym źródłem informacji respondentów z Niemiec o ofercie handlowej są strony internetowe producentów. Korzystają z nich, więcej niż z innych źródeł informacji, respondenci kupujący odzież i obuwie, sprzęt RTV i fotograficzny, artykuły sportowe i turystyczne, kosmetyki i żywność. Badani kupujący książki multimedia częściej wykorzystują informacje ze sklepów/aukcji internetowych, a kupujący komputery i oprogramowanie informacje z forów internetowych (tabela 5).

$5 \quad$ Przedstawione wyniki badań dotyczące zachowań nabywczych e-konsumentów z Niemiec korespondują z innymi wynikami badań w tym zakresie. Por. Stolecka-Makowska (2015), s. 723-731; Maciejewski (2015), s. 358-369. 
Rysunek 4. Przyczyny zakupu produktów przez internet, a nie tradycyjnie, przez e-konsumentów z Niemiec [\%]

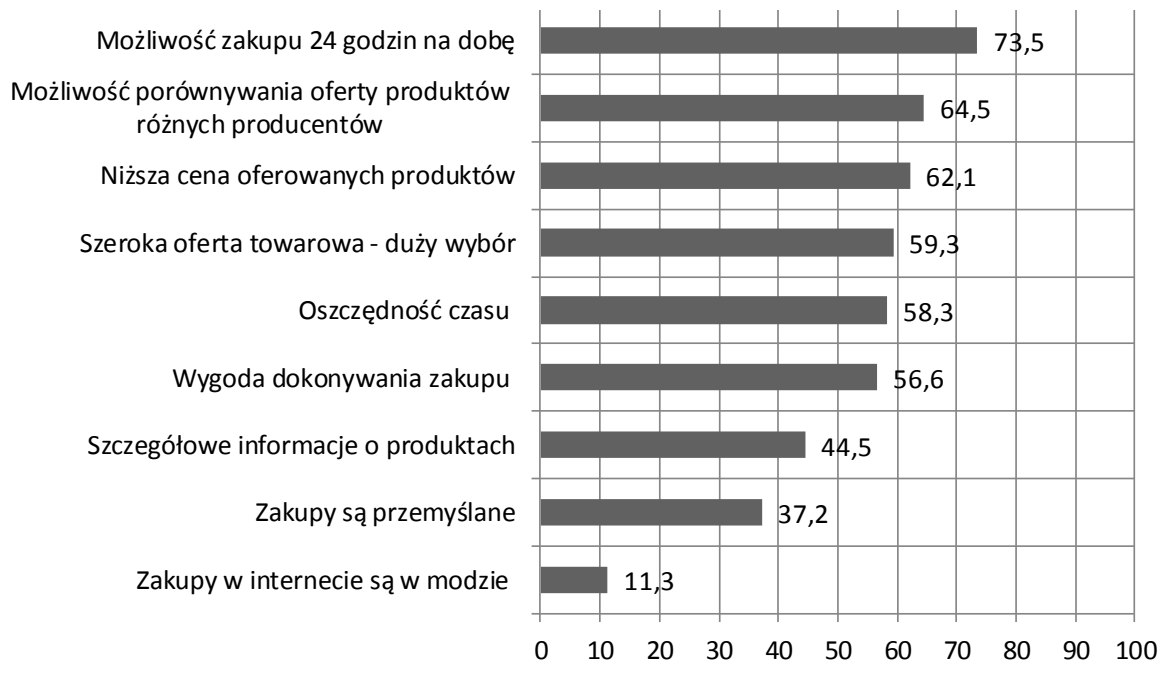

Źródło: opracowanie własne.

Tabela 5. Internetowe źródła informacji o produktach wykorzystywane przez e-konsumentów z Niemiec [\%]

\begin{tabular}{|l|c|c|c|c|c|}
\hline \multicolumn{1}{|c|}{ Wyszczególnienie } & $\begin{array}{c}\text { Strony WWW } \\
\text { producentów }\end{array}$ & $\begin{array}{c}\text { Sklepy/aukcje } \\
\text { internetowe }\end{array}$ & $\begin{array}{c}\text { Fora } \\
\text { internetowe }\end{array}$ & $\begin{array}{c}\text { Porównywarki } \\
\text { cen }\end{array}$ & $\begin{array}{c}\text { Reklama } \\
\text { w sieci }\end{array}$ \\
\hline Komputery i oprogramowanie & 48,3 & 33,9 & 52,5 & 35,9 & 16,0 \\
\hline Książki i multimedia & 35,9 & 37,7 & 33,7 & 19,3 & 17,4 \\
\hline Odzież i obuwie & 40,6 & 36,7 & 19,9 & 21,9 & 23,5 \\
\hline RTV i foto & 38,9 & 32,9 & 34,9 & 28,0 & 14,4 \\
\hline Sport i turystyka & 36,5 & 30,2 & 27,2 & 22,7 & 15,0 \\
\hline Kosmetyki & 31,4 & 29,0 & 27,8 & 16,8 & 15,8 \\
\hline Żywność & 22,9 & 18,3 & 18,9 & 11,4 & 13,0 \\
\hline
\end{tabular}

Źródło: opracowanie własne.

\section{Postępowanie e-konsumentów ze Szwajcarii}

Respondenci ze Szwajcarii chętnie dokonują zakupów on-line, ale podobnie jak badani z Austrii i Niemiec rzadziej dotyczy to produktów z branży FMCG. Ponad połowa badanych kupuje przez internet książki i multimedia oraz komputery i oprogra- 
mowanie, a około $40 \%$ odzież i obuwie oraz artykuły sportowe i turystyczne. Kosmetyki przez internet kupuje 23,9\%, a żywność niemal 10\% badanych Szwajcarów (rysunek 5).

Rysunek 5. Produkty kupowane w internecie przez e-konsumentów ze Szwajcarii [\%]

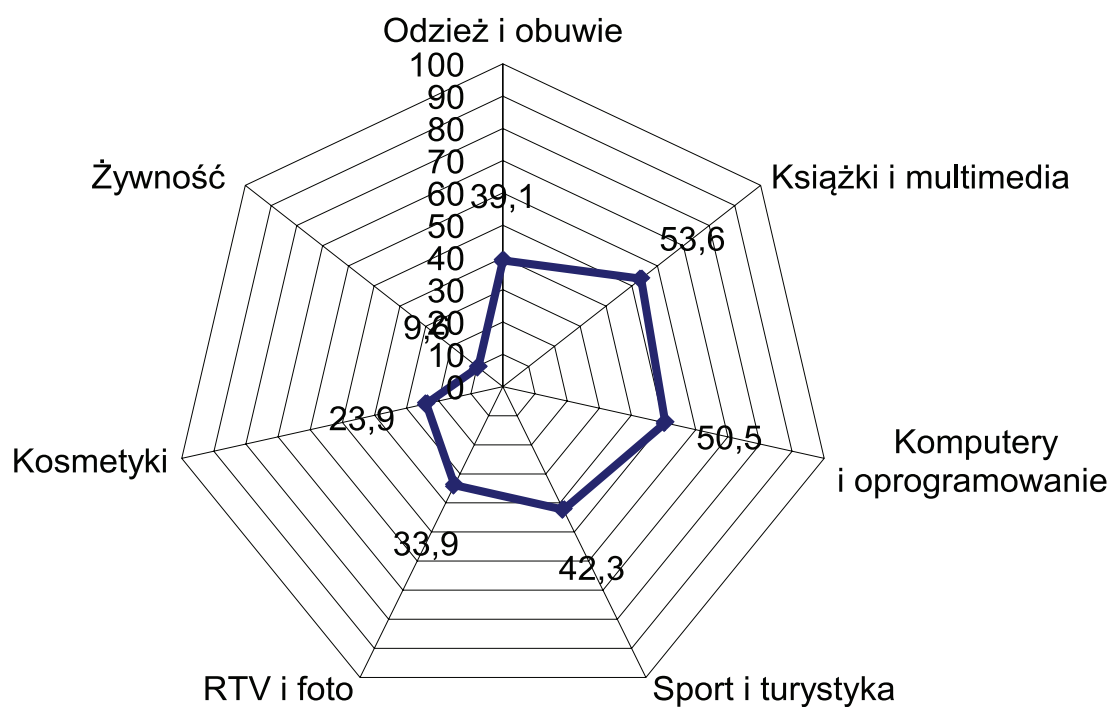

Źródło: opracowanie własne.

Prawie 2/3 badanych Szwajcarów jako przyczynę dokonywania zakupów on-line wskazuje możliwość zakupu 24 godziny na dobę, możliwość porównywania oferty produktów różnych producentów oraz szeroką ofertę towarową w internecie. Ponad połowa badanych wskazuje także na niższe ceny produktów w internecie w porównaniu z tradycyjnymi sklepami, wygodę dokonywania zakupów oraz oszczędność czasu. Na modę dokonywania zakupów on-line wskazał niemal co piąty badany (rysunek 6).

Podstawowym internetowym źródłem informacji respondentów ze Szwajcarii o ofercie handlowej są strony internetowe producentów. Korzystają z nich, więcej niż z innych źródeł informacji, respondenci kupujący wszystkie badane grupy produktów. Porównywarki cen oraz fora internetowe to ważne źródło informacji dla kupujących komputery i oprogramowanie (wykorzystywane częściej niż przy zakupie innych produktów). Informacje ze sklepów/aukcji internetowych badani Szwajcarzy wykorzystują chętniej przy zakupie książek i multimediów niż innych produktów, a z kolei ważnym źródłem informacji przy zakupie odzieży i obuwia niż innych produktów jest reklama w internecie (tabela 6). 
Rysunek 6. Przyczyny zakupu produktów przez internet, a nie tradycyjnie, przez e-konsumentów ze Szwajcarii [\%]

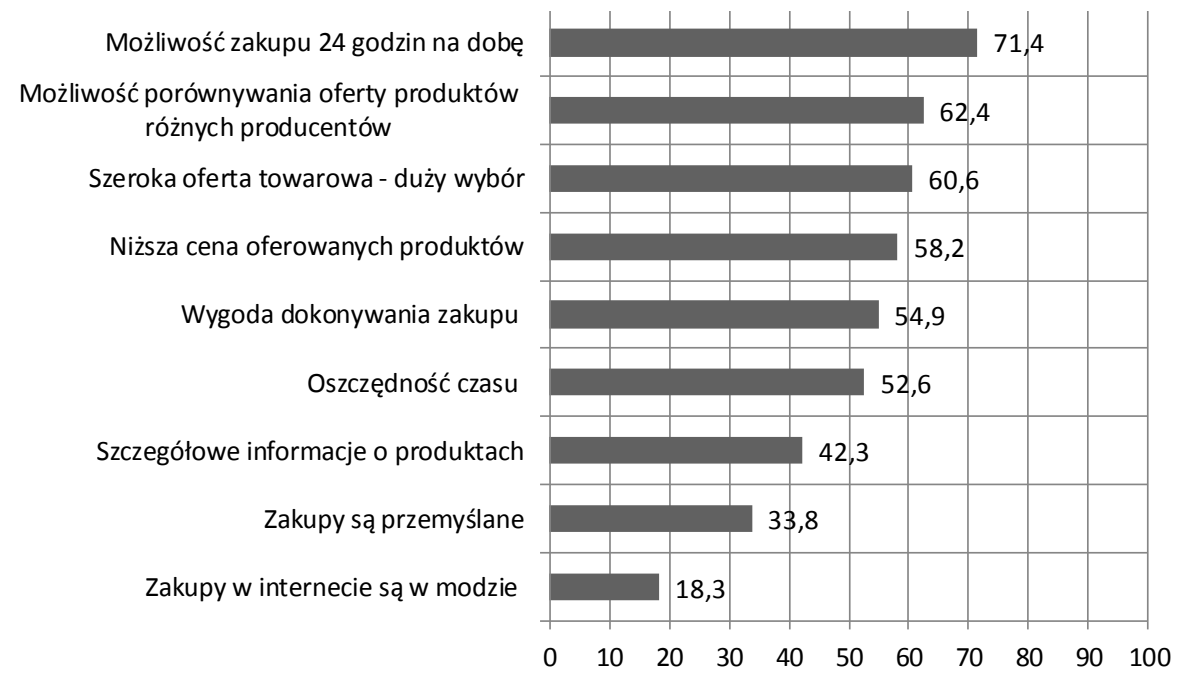

Źródło: opracowanie własne.

Tabela 6. Internetowe źródła informacji o produktach wykorzystywane przez e-konsumentów ze Szwajcarii [\%]

\begin{tabular}{|l|c|c|c|c|c|}
\hline \multicolumn{1}{|c|}{ Wyszczególnienie } & $\begin{array}{c}\text { Strony WWW } \\
\text { producentów }\end{array}$ & $\begin{array}{c}\text { Sklepy/aukcje } \\
\text { internetowe }\end{array}$ & $\begin{array}{c}\text { Fora } \\
\text { internetowe }\end{array}$ & $\begin{array}{c}\text { Porównywarki } \\
\text { cen }\end{array}$ & $\begin{array}{c}\text { Reklama } \\
\text { w sieci }\end{array}$ \\
\hline Komputery i oprogramowanie & 58,5 & 29,6 & 44,4 & 32,4 & 13,4 \\
\hline Książki i multimedia & 40,8 & 33,8 & 27,5 & 16,2 & 14,8 \\
\hline Odzież i obuwie & 43,0 & 33,1 & 19,7 & 13,4 & 20,4 \\
\hline RTV i foto & 40,8 & 24,6 & 27,5 & 19,7 & 9,9 \\
\hline Sport i turystyka & 36,6 & 28,9 & 19,0 & 16,9 & 14,8 \\
\hline Kosmetyki & 28,2 & 19,7 & 23,2 & 12,0 & 12,7 \\
\hline Żywność & 25,4 & 21,1 & 12,0 & 5,6 & 12,7 \\
\hline
\end{tabular}

Źródło: opracowanie własne.

\section{Podsumowanie}

E-konsumenci z Austrii, Niemiec i Szwajcarii są aktywnymi i świadomymi nabywcami produktów w internecie. Można obserwować już symptomy przechodzenia z zachowań nabywczych do e-zachowań nabywczych (z czym mamy do czy- 
nienia, gdy e-konsument częściej kupuje produkty w internecie niż w placówkach stacjonarnych). Ma to już miejsce w przypadku zakupu książek i multimediów we wszystkich badanych krajach oraz komputerów i oprogramowania w Niemczech i Szwajcarii. Determinanty zakupu produktów w internecie, w tym możliwość zakupu 24 godziny na dobę, możliwość porównywania oferty produktów różnych producentów, jak również niższa cena niż w przypadku kupowania produktów w tradycyjnych sklepach, wskazują na duży potencjał rozwoju tej formy sprzedaży. W obszarze e-zachowań nabywczych rodzi się zjawisko upodobniania się zachowań konsumentów (co jest zjawiskiem symptomatycznym dla konsumpcji postmodernistycznej), które można już obserwować wśród badanych e-konsumentów z Austrii, Niemiec i Szwajcarii. Co przyniesie przyszłość? Biorąc pod uwagę rozwój e-handlu na całym świecie, można się spodziewać wzrostu zainteresowania konsumentów zakupami w internecie. Czy jednak wszystkie fazy procesu zakupu będą miały miejsce w internecie? Czy może dominować będzie efekt ROPO (por. Wolny, 2015, s. 849-859)? Czas pokaże.

\section{Literatura}

http://appsso.eurostat.ec.europa.eu (30.11.2015).

http://ec.europa.eu/ (30.11.2015).

http://ecommercenews.eu (30.11.2015).

http://www.bfs.admin.ch (30.11.2015).

Jaciow, M., Wolny, R. (2011). Polski e-konsument. Typologia, zachowania. Gliwice: OnePress.

Jaciow, M., Wolny, R., Stolecka-Makowska, A. (2013). E-consumer in Europe. Comparative Analysis of Behaviors'. Gliwice: OnePress.

Maciejewski, G. (2015). Wybrane aspekty zachowań zakupowych konsumentów w Niemczech. Marketing i Rynek, 8, 358-369.

Measuring the Information Society Report 2014 (2015). Switzerland: International Telecommunication Union.

Stolecka-Makowska, A. (2015). Zachowania nabywcze e-konsumentów w Niemczech - studium badawcze. Marketing i Rynek, 8, 723-731.

Wolny, R. (2015). Efekt ROPO w procesie zakupu usług konsumentów z Niemiec. Marketing i Rynek, 8, 849-859. 


\title{
ON-LINE PURCHASING BEHAVIOR OF E-CONSUMERS IN AUSTRIA, GERMANY AND SWITZERLAND
}

\begin{abstract}
The aim of the article is to present selected determinants of e-purchasing behavior of consumers in Austria, Germany and Switzerland and to present the results of research of e-purchasing behavior. The article presents the results of field research conducted on-line survey (years 2014-2015). The research shows that e-consumers in selected European countries are active buyers of products on the Internet. They use of on-line information sources, and also fundamental determinants of on-line shopping is possible to compare offers various manufacturers and the opportunity to purchase 24 hours a day.
\end{abstract}

Translated by Robert Wolny

Keywords: purchasing behaviour, e-consumer, Austria, Germany, Switzerland JEL Codes: M39, L81, O39 
